Sławomir Grabiszewski ${ }^{1}$

Uniwersytet Kardynała Stefana Wyszyńskiego w Warszawie

\title{
Nauczanie Benedykta XVI o Duchu Świętym na podstawie homilii w uroczystość Zesłania Ducha Świętego
}

Duch Święty jest jedną z Osób Trójcy Świętej, jest współistotny Ojcu i Synowi i „z Ojcem i Synem wspólnie odbiera uwielbienie i chwałę”. Działa z Ojcem i Synem od początku, aż do wypełnienia zamysłu naszego zbawienia.Jednakże dopiero od czasów ostatecznych, zapoczątkowanych przez wcielenie, zostaje On objawiony i udzielony oraz uznany i przyjęty jako Osoba ${ }^{3}$. Ewangelista Jan pisze, że podczas wieczerzy paschalnej, która poprzedziła dzień męki i śmierci, Jezus przemówił do Apostołów w takich słowach: „A o cokolwiek prosić będziecie w imię moje, to uczynię, aby Ojciec był otoczony chwałą w Synu... Ja zaś będę prosił Ojca, a innego Pocieszyciela da wam, aby z wami był na zawsze - Ducha Prawdy" (J 14, 13.16n). Tego właśnie Ducha Prawdy nazywa Chrystus Parakletem. „Parákletos” zaś znaczy „Pocieszyciel”, a znaczy również „Orędownik” lub „Rzecznik”. Chrystus nazywa Ducha Prawdy „innym” Pocieszycielem,

1 Ks. mgr lic. Sławomir Grabiszewski - proboszcz parafii św. Michała Archanioła w Dąbrowie Wielkiej, prezbiter diecezji włocławskiej. E-mail: sgrabiszewski@diecezja.wloclawek.pl.

2 Symbol nicejsko-konstantynopolitański: Katechizm Kościoła katolickiego, Poznań 1994 (odtąd skrót: KKK), 245.

3 KKK 258. 
drugim, gdyż On sam: Jezus Chrystus, jest pierwszym Pocieszycielem (por. 1 J 2,1), pierwszym nosicielem i dawcą Dobrej Nowiny. Duch Święty przychodzi po Nim i za Jego sprawą, ażeby dzieło Dobrej Nowiny zbawienia kontynuować w świecie przez Kościół ${ }^{4}$. Chrystus pozostawił nam w spadku odkupienie i zbawienie, przelewając swoją własną krew, ale to Duch Święty jest wykonawcą owego testamentu i to On pozwala nam stać się posiadaczami tego odkupienia i zbawienia ${ }^{5}$.

A zatem rodzi się potrzeba ciągłego odkrywania Osoby Ducha Świętego i permanentnego coraz głębszego otwierania się na Jego działanie, aby wierni stali się „posiadaczami” odkupienia i zbawienia, przez coraz pełniejsze odnowienie w sobie Bożego synostwa, głębsze poznanie własnej tożsamości chrześcijańskiej i przyjęcie postawy ucznia - misjonarza.

Celem artykułu jest refleksja teologiczna nad homiliami papieża Benedykta XVI, wygłoszonymi w uroczystość Zesłania Ducha Świętego. Zostanie ona przeprowadzona według następującego planu: 1. Ogólna charakterystyka homilii Benedykta XVI w uroczystość Zesłania Ducha Świętego. 2. Źródła homilii Benedykta XVI w uroczystość Zesłania Ducha Świętego. 3. Tematy teologiczne w papieskim przepowiadaniu.

\section{Ogólna charakterystyka homilii Benedykta XVI w uroczystość Zesłania Ducha Świętego}

Papież Benedykt XVI sprawował posługę biskupa Rzymu od 19 kwietnia 2005 roku do 28 lutego 2013 roku. W czasie swojego pontyfikatu, podczas celebracji liturgicznych sprawowanych w uroczystość Pięćdziesiątnicy, wygłosił siedem homilii ${ }^{6}$. Chociaż różnią się one w szczegółach, ogólny ich przebieg można zamknąć w następującym schemacie: Po pozdrowieniu zgromadzonych powszechnie używaną formą „drodzy bracia i siostry” nawiązuje papież do tajemnicy dnia, uobecnianej w czynnościach liturgicznych. Mówi o niej w sensie ogólnym, czasem wskazuje na pewien

4 Jan Paweł II, enc. Dominum et Vivificantem [dalej: DeV], 3.

5 Matta el-Maskine, Komunia miłości, przeł. J. Dembska, Tyniec-Kraków 2008, s. 261.

6 Wyjątkiem jest rok 2007. 
aspekt tajemnicy Zesłania Ducha Świętego, który zostanie omówiony, lub na imperatyw wypływający z przeżywanej liturgii. Po tej krótkiej introdukcji homilista omawia czytania liturgiczne, wydobywając piękno kerygmatu, w odniesieniu do życia słuchaczy. Na koniec kaznodzieja kieruje zachętę do trwania razem na modlitwie ${ }^{7}$ i otwarcia się na dary Ducha Świętego ${ }^{8}$, do wejścia w modlitwę Kościoła ${ }^{9}$, który w duchowej łączności z Maryją ${ }^{10}$ błaga o nowe wylanie Ducha Świętego: „Emitte Spiritum tuum et creabuntur, et renovabis feciem terrae - Ześlij Twojego Ducha, a wszystko zostanie na nowo stworzone i odnowisz oblicze ziemi"11.

\section{2. Źródła homilii Benedykta XVI w uroczystość Zesłania Ducha Świętego}

Źródłami, z których korzysta Benedykt XVI w swoich homiliach, są: Pismo Święte, liturgia, nauczanie ojców Kościoła, magisterium Kościoła, doświadczenie świętych.

\subsection{Pismo Święte}

Podstawowym źródłem przepowiadania Benedykta XVI w czasie celebracji święta Pentekosté są teksty Pisma Świętego przeznaczone na ten dzień. Wszystkie one są tematycznie ze sobą powiązane. Ewangelia opisuje, co działo się w Wielką Niedzielę wieczorem. Zmartwychwstały Pan

7 Benedykt XVI, Homilia w uroczystość Zesłania Ducha Świętego 2012 r., „L'Osservatore Romano" wydanie polskie 7-8 (345) 2012, s. 35.

8 Benedykt XVI, Homilia w uroczystość Zesłania Ducha Świętego 2011 r., "L’Osservatore Romano" wydanie polskie 8-9 (336) 2011, s. 28.

9 Benedykt XVI, Homilia w uroczystość Zesłania Ducha Świętego 2010 r., „L'Osservatore Romano" wydanie polskie 7 (324) 2010, s. 48.

10 Benedykt XVI, Homilia w uroczystość Zesłania Ducha Świętego 2009 r., „L'Osservatore Romano" wydanie polskie 10 (317) 2009, s. 10.

11 Benedykt XVI, Homilia w uroczystość Zesłania Ducha Świętego 2008 r., „L'Osservatore Romano" wydanie polskie 6 (304) 2008, s. 48. Nieco inny charakter i końcowe zalecenie ma homilia z 2005 roku, która w dużej części skierowana jest do diakonów przyjmujących święcenia kapłańskie. 
przychodzi do apostołów mimo zamkniętych drzwi, obdarzając ich pokojem i tchnie na nich, mówiąc: „Weźmijcie Ducha Świętego!” (J 20, 22) ${ }^{12}$. W interpretacji tej perykopy ojciec święty odwołuje się do opisu stworzenia człowieka z Księgi Rodzaju, cytując wiersz siódmy drugiego rozdziału tej księgi ${ }^{13}$. To odwołanie ubogaca rozumienie wersu 22 z rozdziału 20 Ewangelii św. Jana i podkreśla jedność całego Pisma Świętego. Ciekawe jest to, że w trzech homiliach zamiast tekstu J 20, 19-23 zostały użyte inne perykopy z Ewangelii Janowej ${ }^{14}$.

Szczególną rolę w tym obficie zastawionym stole słowa Bożego pełni pierwsze czytanie, które relacjonuje wydarzenie Pięćdziesiątnicy. Do niego papież odwołuje się w każdej z siedmiu homilii. Pogłębiona analiza tekstu wydobywa na światło dzienne wciąż nowe elementy biblijnego obrazu, które poddane refleksji teologicznej stają się życiowymi wskazaniami dla słuchaczy słowa Bożego.

Tłem do czytań z tej wielkiej uroczystości Zesłania Ducha Świętego są teksty biblijne proponowane podczas celebracji wigilii: $\mathrm{Rdz} 11, \mathrm{Wj} 19$, Ez 37, Jl 3. Teksty te zapowiadają i antycypują dar Ducha (Ez 37, Jl 3), mówią o jego skutkach (Rdz 11) albo też dostarczają języka i obrazów dla Łukaszowego opisu z Dziejów Apostolskich (Wj 19) ${ }^{15}$. Dwa z nich, tj. Rdz 11, opowiadający o historii wieży Babel i Wj 19 mówiący o teofanii na górze Synaj są dla Benedykta XVI jakby kluczem do poszerzonej interpretacji tekstów z dnia i opisania wielkości daru Pięćdziesiątnicy. Tego klucza interpretacyjnego używa papież niemal w każdej homilii' ${ }^{16}$.

12 Tekst Ewangelii J 20, 19-23 analizuje papież w homiliach z 2005, 2008, 2009 i 2011 roku.

13 To odwołanie jest obecne w homiliach z 2005 i 2011 roku.

14 W homilii z 2006 i 2012 roku został użyty do liturgi tekst z J 16, a w homilii 2010 roku tekst z J 14.

15 P. Gironi, Dom na skale. Komentarze do czytań niedzielnych i świątecznych. Lata A B C, tłum. K. Stopa, Częstochowa 2003, s. 67.

16 Wyjątkiem dla Rdz 11 jest homilia z 2009 i z 2011 roku, a dla Wj 19 homilia z 2010 i z 2012 roku. 
Drugie czytanie liturgiczne jest zaledwie zauważone w trzech homiliach $^{17}$, a psalm po pierwszym czytaniu w dwóch ${ }^{18}$.

Ponadto homilista dość często odsyła słuchaczy do tekstu Dz 1, a w pojedynczych przypadkach do tekstów: $1 \mathrm{Krl} \mathrm{19,} \mathrm{Iz} \mathrm{42,} \mathrm{Ef} \mathrm{2,} \mathrm{Mk} \mathrm{16,} \mathrm{J} \mathrm{14,} \mathrm{Łk} \mathrm{12,}$ Łk 1, Pwt 4, Rdz 1.

\subsection{Liturgia}

Ojcowie II Soboru Watykańskiego, podkreślając wyjątkową naturę głoszenia słowa w ramach liturgii świętej, zaznaczyli, że winno ono czerpać treść przede wszystkim ze źródeł Pisma Świętego i liturgii ${ }^{19}$. A zatem wyjaśnienie jakiegoś aspektu spośród stałych lub zmiennych tekstów mszy danego dnia, z uwzględnieniem obchodzonego misterium ${ }^{20}$, jest ważnym źródłem homilii. Bez uwzględnienia tego źródła łatwo można zagubić cel przepowiadania, jakim jest głoszenie paschalnego misterium Chrystusa, które urzeczywistnia się przez ofiarę mszy świętej ${ }^{21}$.

Benedykt XVI w omawianych homiliach czerpie z tego źródła w sposób jakby naturalny. Mówi bowiem o wydarzeniu Pentekosté, które przekonująco objawia wszystkim narodom „wielkie dzieła Boże” (Dz 2, 11) okazane w śmierci i zmartwychwstaniu Jezusa, a celebrowane w czynnościach liturgicznych.

\subsection{Ojcowie Kościoła}

Kolejnym źródłem dla homilii są pisma ojców Kościoła. Z tego źródła korzysta papież w dwóch przypadkach. W homilii z 2008 roku przytacza określenie Societas Spiritus - społeczność Ducha, którym św. Augustyn określa Kościół. Następnie cytuje św. Ireneusza, by ukazać związek

17 W homiliach z 2005 i 2011 roku. W homilii z 2012 roku jako drugie czytanie użyto Ga 5, 16 nn.

18 W homiliach z 2009 i 2011 roku.

19 Sobór Watykański II, konst. Sacrosanctum Concilium, 35,2.

20 Ogólne wprowadzenie do Mszału rzymskiego (trzecie wydanie wzorcowe), Rzym 2002,65 .

${ }^{21}$ Zob. Wprowadzenie do drugiego wydania Lekcjonarza mszalnego (1981), 24. 
„między Duchem Chrystusa i Jego mistycznym Ciałem, czyli Kościołem”22. Natomiast w homilii z 2010 roku, cytując Orygenesa, przytacza słowa Jezusa, które nie występują w Piśmie Świętym, ale które możliwe, że są autentyczne ${ }^{23}$.

\subsection{Magisterium Kościoła}

Również Magisterium Kościoła jest ważnym źródłem homilii. Oficjalne nauczanie Kościoła chroni autentyczność przepowiadania przed wypaczeniem, precyzyjnie formułuje i wyjaśnia prawdy wiary przy pomocy terminów teologicznych i filozoficznych ${ }^{24}$. Papież sięgnął do tego źródła w homilii z 2010 roku, odsyłając słuchaczy do pierwszego punktu konstytucji Vaticanum II Lumen gentium.

\section{5. Święci}

W świętych „Bóg ukazuje ludziom naocznie swoją obecność i swoje oblicze. W nich do nas sam przemawia i daje nam znak swego Królestwa"25. Dlatego święci „utwierdzają cały Kościół w świętości [...], nieustannie wstawiają się za nami u Ojca, ofiarując Mu zasługi, które przez jedynego Pośrednika między Bogiem a ludźmi, Jezusa Chrystusa, zdobyli na ziemi [...] Ich braterska troska bardzo wspomaga naszą słabość" ${ }^{26}$. Wśród nich „najznakomitszym i całkiem szczególnym członkiem Kościoła” ${ }^{27}$ jest Maryja, którą Bóg postawił jako wzór ducha pobożności² i jako nauczycielkę dla wszystkich chrześcijan ${ }^{29}$. Podkreślając tę wyjątkową rolę Maryi, Benedykt XVI przypomina słuchaczom o miłości do Matki Chrystusa

22 Benedykt XVI, Homilia w uroczystość Zesłania Ducha Świętego 2008 r., dz. cyt., s. 47.

${ }^{23}$ „Kto jest przy Mnie, jest przy ogniu”, Orygenes, Omelia su Geremia L. I [III], cyt. za: Benedykt XVI, Homilia w uroczystość Zesłania Ducha Świętego 2010 r., dz. cyt., s. 48.

24 Por. H. Sławiński, Chrystus urzeczywistnił Pismo. Homilie na rok A, Kraków 2007, s. 14-15.

25 Sobór Watykański II, konst. Lumen gentium [dalej: LG], 50.

26 LG 49.

27 LG 53.

28 Paweł VI, adhort. apost. Marialis cultus, 16.

29 Paweł VI, adhort. apost. Marialis cultus, 21. 
i przyjęcia Jej do swojego serca ${ }^{30}$, zachęca, by razem z Nią modlić się o nowe wylanie Ducha Świętego Pocieszyciela ${ }^{31} \mathrm{i}$ by za Jej przykładem mniej „przejmować się” działaniem, a w większym stopniu być oddanym modlitwie ${ }^{32}$.

Nauczycielami dla wszystkich chrześcijan są także beatyfikowani i kanonizowani bohaterowie doskonałości chrześcijańskiej ukazujący różnorodne formy świętości ${ }^{33}$. Na nich w ogólności, bez konkretnych przykładów, wskazuje ojciec święty w homilii z 2009 roku $^{34}$.

\section{Główne tematy teologiczne}

Głównymi zagadnieniami teologicznymi, które dają się wyróżnić w homiliach Benedykta XVI, są: relacja Pięćdziesiątnicy chrześcijańskiej do Pięćdziesiątnicy żydowskiej, zesłanie Ducha Świętego na tle opowiadania o wieży Babel, Duch Święty jako protagonista Kościoła, Kościół jeden i wieloraki, modlitwa.

\subsection{Relacja Pięćdziesiątnicy chrześcijańskiej do Pięćdziesiątnicy żydowskiej}

W niemal wszystkich homiliach wydarzenie Zesłania Ducha Świętego opisane w Dziejach Apostolskich osadza Benedykt XVI w Pięćdziesiątnicy

30 Benedykt XVI, Homilia w uroczystość Zesłania Ducha Świętego 2005 r., „L'Osservatore Romano" wydanie polskie 7-8 (275) 2005, s. 23.

31 Benedykt XVI, Homilia w uroczystość Zesłania Ducha Świętego 2006 r., „L'Osservatore Romano" wydanie polskie 8 (285) 2006, s. 13, por. Benedykt XVI, Homilia w uroczystość Zestania Ducha Świętego 2008 r., dz. cyt., s. 48, por. także Benedykt XVI, Homilia w uroczystość Zestania Ducha Świętego 2012 r., dz. cyt., s. 35.

32 Benedykt XVI, Homilia w uroczystość Zesłania Ducha Świętego 2009 r., dz. cyt., s. 9.

33 Por. Misztal H., Doskonali w miłości. Świeccy święci i błogosławieni, Lublin 1992, s. 411.

34 „Duch Boży, tam gdzie wkracza, rozprasza lęk; daje nam poznać i odczuć, że jesteśmy w rękach Wszechmocy miłości: cokolwiek by się wydarzyło, Jego nieskończona miłość nas nie opuszcza. Dowodzi tego świadectwo męczenników, odwaga wyznawców wiary, nieustraszony zapał misjonarzy, śmiałość głosicieli, przykład wszystkich świętych, wśród których są nawet młodzieńcy i dzieci”. Benedykt XVI, Homilia w uroczystość Zesłania Ducha Świętego 2009 r., dz. cyt., s. 10. 
żydowskiej, która była świętem przymierza ${ }^{35}$. To przymierze zawarł Bóg ze swoim ludem na górze Synaj. W nim Izrael otrzymał przykazania i stał się „ludem poświęconym Panu, Bogu swemu”, który Pan wybrał sobie na własność spośród wszystkich narodów mieszkających na ziemi (Pwt 14, 2). Jak czytamy w Księdze Wyjścia, temu dawnemu paktowi towarzyszyło przerażające objawienie potęgi Pana: „Góra Synaj - czytamy w niej - była cała spowita dymem, gdyż Pan zstąpił na nią w ogniu i unosił się z niej dym jak z pieca, i cała góra bardzo się trzęsła" (Wj 19, 18) ${ }^{36}$. Takie samo jest też tło zawartego w Dziejach Apostolskich opowiadania o zstąpieniu Ducha Świętego: „Nagle dał się słyszeć z nieba szum jakby uderzenie gwałtownego wiatru... Ukazały się im języki jakby z ognia”. Tak jak na Synaju zwołany zostaje cały Izrael jako Lud Boży i otrzymuje dar Prawa, tak Dzieje Apostolskie widzą w dniu Pięćdziesiątnicy narodziny i zwołanie nowej wspólnoty mesjańskiej, na której spoczywa Duch Święty wraz z bogactwem i nowością swoich darów ${ }^{37}$. W homilii z 2006 roku papież ukazuje Pięćdziesiątnicę (chrześcijańską) jako nowy Synaj, jako Święto Nowego Przymierza, w którym przymierze z Izraelem zostaje rozszerzone na wszystkie ludy ziemi, a w homilii z 2011 kontynuuje, że w tym nowym Przymierzu upadają wszystkie bariery starego Prawa i ukazuje się jego najświętsze i niezmienne serce, czyli miłość, którą właśnie Duch Święty przekazuje i szerzy; miłość, która wszystko ogarnia. Zarazem Prawo się rozszerza, otwiera i upraszcza: jest to nowe Przymierze, które Duch „wpisuje” w serca wierzących w Chrystusa ${ }^{38}$.

\subsection{Zesłanie Ducha Świętego na tle opowiadania o wieży Babel}

W pierwszej pod względem chronologicznym homilii wskazuje papież na dar języków, jaki pojawia się w Łukaszowym opisie: „, zaczęli mówić obcymi językami, tak jak im Duch pozwalał mówić [...] i każdy słyszał,

35 Od II wieku przed Chr. Pierwotnie była świętem żniwa. Zob. Encyklopedia katolicka, t. 15, red. E. Gigilewicz i in., Lublin 2011, s.559, zob. także: X. Léon-Dufour, Słownik teologii biblijnej, tłum. K. Romaniuk, Poznań-Warszawa 1985, s. 665.

${ }_{36}$ Benedykt XVI, Homilia w uroczystość Zesłania Ducha Świętego 2008 r., dz. cyt., s. 46.

37 P. Gironi, Dom na skale..., dz. cyt., s. 186.

38 Benedykt XVI, Homilia w uroczystość Zesłania Ducha Świętego 2011 r., dz. cyt., s. 27. 
jak przemawiali w jego własnym języku" (Dz 2, 4.6) ${ }^{39}$. Nie chodzi tu o interpretowanie tego wydarzenia $\mathrm{w}$ jego wymiarze wyłącznie materialnym $^{40}$, lecz o uchwycenie głębszego znaczenia tego, co Duch Święty może zdziałać w ludzkości. Dzięki tej potencji sprawczej Parakleta odmienna i zróżnicowana pod względem języków, zwyczajów i ras ludzkość może mówić jednakowym językiem i rozumieć go. A jest to język tej samej wiary, nadziei i miłości ${ }^{41}$.

W głębszym wyjaśnieniu tego szczególnego zjawiska odwołuje się papież do epizodu związanego z wieżą Babel ${ }^{42}$. Bohaterowie tej biblijnej historii chcą „uczynić sobie znak” ${ }^{43}$, chcą zrealizować się niezależnie od Boga, w sposób autonomiczny i z pełnym pychy poczuciem samowystarczalności. Ten ich wysiłek, ukarany przez Boga rozproszeniem i pomieszaniem języków, sprawia, że tracą podstawową cechę człowieczeństwa: zdolność do zgody, do wzajemnego zrozumienia się i wspólnego działania ${ }^{44}$.

Natomiast w czasie Pięćdziesiątnicy chrześcijańskiej ludzkość powraca do jedności początków i przezwycięża przekleństwo Babelu ${ }^{45}$. Duch Święty daje nowe serce i nowy język, nową zdolność porozumiewania $\operatorname{sie}^{46}$, pokonuje granice i prowadzi ludzi ku sobie nawzajem ${ }^{47}$. Tekst Rdz 11 zawiera ponadczasowe przesłanie. Pragnienie sławy, trwałych

39 Benedykt XVI, Homilia w uroczystość Zesłania Ducha Świętego 2005 r., dz. cyt., s. 21.

40 Nie można go także wykluczyć, ponieważ w pierwszych wspólnotach chrześcijańskich -zwłaszcza Pawłowych (zob. 1 Kor 12-14) faktycznie występował dar języków. P. Gironi, Dom na skale..., dz. cyt., s. 310 .

41 Benedykt XVI, Homilia w uroczystość Zesłania Ducha Świętego 2011 r., dz. cyt., s.27, por. także: Prefacja o Zesłaniu Ducha Świętego.

42 Rdz 11, 1-9, tekst proponowany jako pierwsze czytanie w czasie celebracji liturgicznej wigilii uroczystości Zesłania Ducha Świętego. Odniesienie do tego tekstu robi papież w 5 homiliach.

43 To wydarzenie oznacza samowystarczalność, pychę, zuchwałość, a tym samym wrogość człowieka względem Boga. Por. M. Lurker, Słownik obrazów i symboli biblijnych, tłum. K. Romaniuk, Poznań 1989, s. 21; zob. także B. Metzger, M. Coogman, Słownik wiedzy biblijnej, przekł. A. Karpowicz i in., Warszawa 2004, s. 798.

44 Benedykt XVI, Homilia w uroczystość Zesłania Ducha Świętego 2012 r., dz. cyt., s. 34.

45 Benedykt XVI, Homilia w uroczystość Zesłania Ducha Świętego 2008 r., dz. cyt., s. 47.

46 Benedykt XVI, Homilia w uroczystość Zesłania Ducha Świętego 2012 r., dz. cyt., s. 34.

47 Benedykt XVI, Homilia w uroczystość Zesłania Ducha Świętego 2005 r., dz. cyt., s. 22. 
osiągnięć i dążenie do niezależności jest obecne także w naszych czasach. A sprzyja temu gwałtowny rozwój nauki i techniki, który daje nam poczucie panowania nad światem i samowystarczalności, w którym odniesienie do Boga staje się niepotrzebne. I tak mimo większej możliwości komunikowania się i pozyskiwania istoty ludzkie brną w ślepy zaułek nieufności jednych ku drugim, podejrzliwości i obaw jednych przed drugimi, do tego stopnia, że jedni stają się niebezpieczni dla drugich ${ }^{48}$. W tej sytuacji, po ludzku bez wyjścia, jest tylko jedno rozwiązanie, które podsuwa celebracja święta Pentekosté: Wejście w modlitwę Kościoła, który błaga o nowe wylanie Ducha Świętego z postawą otwartości na Jego dary ${ }^{49}$.

\subsection{Duch Święty jako protagonista Kościoła}

Tematem najobszerniej poruszanym we wszystkich wyżej wymienionych homiliach jest temat Kościoła. Słowo „Kościół” (ekklesia, z greckiego ek-kalein - „wołać z”) oznacza „zwołanie”. Określa ono zgromadzenie ludu, na ogół o charakterze religijnym. Jest to pojęcie często używane w Starym Testamencie w języku greckim w odniesieniu do zgromadzenia ludu wybranego przed Bogiem, przede wszystkim pod górą Synaj, gdzie Izrael otrzymał Prawo i został ustanowiony przez Boga Jego świętym ludem $^{50}$. W Nowym Testamencie zgromadzeniem tym jest nowy lud Boży, nowy Izrael. To „nowe zwołanie” rozpoczął Chrystus głoszeniem radosnej nowiny o nadejściu królestwa Bożego ${ }^{51}$, dopełnił przez całkowity dar z siebie zrealizowany na krzyżu, a objawił je w dzień Pięćdziesiątnicy, gdy w sposób widzialny zesłał Ducha Świętego Pocieszyciela ${ }^{52}$. A zatem Pentekosté, jak uczy Benedykt XVI, jest chrztem Kościoła ${ }^{53}$, jest wydarzeniem, które nadało mu początkowy kształt i impuls do jego misji.

48 Benedykt XVI, Homilia w uroczystość Zesłania Ducha Świętego 2012 r., dz. cyt., s. 34.

49 Por. Benedykt XVI, Homilia w uroczystość Zesłania Ducha Świętego 2010 r., dz. cyt., s. 47, por. także Benedykt XVI, Homilia w uroczystość Zesłania Ducha Świętego 2008 r., dz. cyt., s. 46.

50 KKK 751.

51 LG 5.

52 Por. Pius XII, enc. Mistici Corporis, cyt. za: W. Granat, Dogmatyka katolicka: synteza, Lublin 1967, s. 267.

53 Benedykt XVI, Homilia w uroczystość Zesłania Ducha Świętego 2012 r., dz. cyt., s. 34. 
Kościół więc nie powstaje z woli człowieka, z jego refleksji, umiejętności ani z jego zdolności organizacyjnych, bowiem gdyby tak było, już dawno przestałby istnieć, tak jak przemijają wszystkie rzeczy ludzkie, lecz jest Ciałem Chrystusa, ożywianym przez Ducha Świętego ${ }^{54}$. Dlatego nie można skuteczności misyjnej mierzyć starannym przygotowaniem programów duszpasterskich i ich inteligentną realizacją poprzez wypełnianie konkretnych zadań. Owszem, to wszystko jest ważne, ale zanim podejmiemy jakiekolwiek działanie, potrzebna jest Jego (Ducha) inicjatywa, bo On, Duch jest prawdziwym protagonistą Kościoła. Nasze istnienie oraz nasze działania swymi korzeniami sięgają pełnego mądrości i troski milczenia Boga $^{55}$. W tym świetle zrozumiała jest, może nieco szokująca wskazówka, by Kościół mniej „przejmował się” działaniem, a w większym stopniu był oddany modlitwie ${ }^{56}$. Jej paradygmat znajdujemy w 1 rozdziale Dziejów Apostolskich: „Wszyscy oni trwali jednomyślni na modlitwie razem z Maryją" (Dz 1, 14). To „trwanie w jedności na modlitwie” jest odpowiedzią na słowo Pana, który przed wstąpieniem do nieba przykazał apostołom „nie odchodzić z Jerozolimy, ale oczekiwać, aż spełni się obietnica Ojca" (por. Dz 1, 4-5). Czyli prosił ich, by pozostali razem na modlitwie i w ten sposób przygotowali się na przyjęcie daru Ducha Świętego ${ }^{57}$. Ich zgoda na słowo Pana staje się warunkiem do tego, aby zstąpił Duch Święty; a przesłanką tej zgody jest modlitwa ${ }^{58}$; co ważne, zawsze wraz Maryją ${ }^{59}$ - Jej obecność bowiem „sprowadza” Ducha Świętego, jak to było w wydarzeniu Nawiedzenia Najświętszej Maryi Panny, które Benedykt XVI określa jako „małą pięćdziesiątnicę”, owocującą w sercach Elżbiety i Maryi radością i uwielbieniem ${ }^{60}$.

54 Benedykt XVI, Homilia w uroczystość Zesłania Ducha Świętego 2011 r., dz. cyt., s. 27.

55 Benedykt XVI, Homilia w uroczystość Zesłania Ducha Świętego 2006 r., dz. cyt., s. 12.

56 Benedykt XVI, Homilia w uroczystość Zesłania Ducha Świętego 2009 r., dz. cyt., s. 9.

57 Benedykt XVI, Homilia w uroczystość Zesłania Ducha Świętego 2006 r., dz. cyt., s. 12.

58 Benedykt XVI, Homilia w uroczystość Zesłania Ducha Świętego 2009 r., dz. cyt., s. 8.

59 „Kościół trwa na modlitwie z Maryją. Owo zjednoczenie modlącego się Kościoła z Matką Chrystusa należy od początku do tajemnicy Kościoła. Bogarodzica jest obecna w tej tajemnicy tak, jak jest obecna w tajemnicy swojego Syna", DeV 66.

60 Mówił o tym papież w 2009 roku. Wtedy Zesłanie Ducha Świętego przypadło na ostatni dzień maja - dzień kiedy zazwyczaj obchodzi się święto Nawiedzenia Najświętszej Maryi Panny. 
Ten „pierwszy czyn” rodzącego się Kościoła nie był aktem jednorazowym. Choć w sensie historycznym Kościół wyszedł z Wieczernika w dniu Pięćdziesiątnicy, to $\mathrm{w}$ sensie duchowym powinien ciągle $\mathrm{w}$ nim trwać ${ }^{61}$. Od wierności wobec pierwotnego habitus zależy kondycja Kościoła, jego młodość, entuzjazm, „atrakcyjność”. Bowiem uczeń Chrystusa może wraz Maryją trwać na modlitwie, przyjąć postawę nabożnego oczekiwania na dar Boga, z pokorą i w ciszy wsłuchując się w Jego Słowo ${ }^{62}$, ale głosić „wielkie dzieła Boże” (Dz 2,11) może na tyle, „na ile mu Duch Święty pozwala mówić" (por. Dz 2, 4), bo On - Duch jest protagonistą Kościoła.

\subsection{Kościół jeden i wieloraki}

Katechizm Kościoła katolickiego naucza, że Kościół jest powszechny (katolicki) ${ }^{63} \mathrm{w}$ podwójnym znaczeniu. Po pierwsze dlatego, że istnieje w nim pełnia Ciała Chrystusa zjednoczona z Głową, w wyniku czego Kościół otrzymuje od Niego „pełnię środków zbawienia”, której On chciał mu udzielićc ${ }^{64}$ I po drugie jest powszechny, ponieważ został posłany przez Chrystusa do całego rodzaju ludzkiego ${ }^{65}$. Temat powszechności Kościoła w tym drugim znaczeniu rozwija Benedykt XVI w swoich kazaniach na uroczystość Zielonych Świąt. Następca św. Piotra głosi, że Kościół jest katolicki od pierwszej chwili swego istnienia, i że jego powszechność nie jest owocem późniejszego przyłączania się różnych wspólnot. Od pierwszej chwili Duch Święty stworzył go bowiem jako Kościół wszystkich ludów; obejmujący cały świat ${ }^{66}$, ponad wszystkimi

\footnotetext{
$61 \quad$ DeV 66.

${ }^{62}$ Benedykt XVI, Homilia w uroczystość Zesłania Ducha Świętego 2009 r., dz. cyt., s. 8-9.

63 Słowo „powszechny” (,katolicki”) oznacza „uniwersalny”, czyli „cały” lub „zupełny”. por. KKK 830.

64 KKK 830.

65 KKK 831.

66 „Pośród narodów reprezentowanych w Jerozolimie w dniu Pięćdziesiątnicy Łukasz wymienia także «przybyszów z Rzymu» (Dz 2, 10). W owym czasie Rzym był jeszcze daleki, «obcy» dla rodzącego się Kościoła: ogólnie był on symbolem świata pogańskiego. Lecz moc Ducha Świętego miała poprowadzić świadków «aż po krańce ziemi» (Dz 1, 8), aż do Rzymu. Księga Dziejów Apostolskich kończy się właśnie w momencie, kiedy św. Paweł zrządzeniem Opatrzności dociera do stolicy imperium i tam głosi Ewangelię (por. Dz 28, 30-31). Tym sposobem droga słowa Bożego, która rozpoczęła się w Jerozolimie, dobiega końca, bowiem Rzym
} 
granicami rasy, klasy, narodowości; obalający wszystkie bariery i łączący ludzi w wyznaniu wiary w Boga Jednego i w Trójcy Jedynego. Nie można więc patrzeć na rodzące się $\mathrm{w}$ dniu Pięćdziesiątnicy Mistyczne Ciało Chrystusa jako na wspólnotę lokalną - Kościół jerozolimski li tylko, lecz przede wszystkim trzeba w nim widzieć Kościół powszechny, mówiący językami wszystkich narodów. Z niego narodzą się później wszystkie inne wspólnoty na całym świecie - Kościoły partykularne ${ }^{67}$. Te lokalne wspólnoty nie są częściami składowymi Kościoła powszechnego, bo Kościół katolicki nie jest federacją lokalnych wspólnot ${ }^{68}$, lecz są urzeczywistnieniem jednego i jedynego Kościoła Chrystusowego ${ }^{69}$, który zawsze na nowo staje się tym, czym już jest ${ }^{70}$. To „ciągłe stawanie się nowego Ludu Bożego tym, czym już jest", dokonuje się w pokonywaniu napięcia między jednością a wielorakością ${ }^{71}$. W innym miejscu Benedykt XVI wyjaśnia, że jedności tej nie można pojmować jako swego rodzaju ujednolicenia. Byłby to wówczas raczej model Babelu, czyli narzucenie kultury jedności, którą moglibyśmy określić jako „techniczną”. Biblia mówi bowiem (por. Rdz 11, 1-9), że w Babelu wszyscy mówili jednym językiem. Natomiast w dniu Pięćdziesiątnicy apostołowie mówią różnymi językami, tak aby każdy mógł zrozumieć przesłanie we własnej mowie ${ }^{72}$. Ukazuje się wtedy „,nowy nurt” działania Boga, które rozpoczęło się wraz ze zmartwychwstaniem Chrystusa, działania, które obejmuje człowieka, historię i kosmos. Od Syna Bożego, który umarł i zmartwychwstał, i powrócił do Ojca, spływa teraz na ludzkość z niesłychaną mocą Boże tchnienie, Duch Święty. W mocy tego Ducha dokonuje się proces

reprezentuje cały świat, jest zatem ucieleśnieniem Łukaszowego wyobrażenia katolickości. Powstał Kościół powszechny, Kościół katolicki, który jest przedłużeniem ludu wybranego, przejmuje jego dzieje i misję", Benedykt XVI, Homilia w uroczystość Zesłania Ducha Świętego 2008 r., dz. cyt., s. 47.

67 Benedykt XVI, Homilia w uroczystość Zesłania Ducha Świętego 2008 r., dz. cyt., s. 47.

68 Tę myśl odnaleźć możemy w adhortacji apostolskiej papieża Pawła VI Evangelii nuntiandi w punkcie 62: „Strzeżmy się poglądu, że Kościół powszechny jest sumą lub, jeśli wolno powiedzieć, federacją Kościołów partykularnych".

69 Benedykt XVI, Homilia w uroczystość Zesłania Ducha Świętego 2008 r., dz. cyt., s. 47.

70 Benedykt XVI, Homilia w uroczystość Zesłania Ducha Świętego 2005 r., dz. cyt., s. 21.

71 Por. Benedykt XVI, Homilia w uroczystość Zesłania Ducha Świętego 2008 r., dz. cyt., s. 47.

72 Benedykt XVI, Homilia w uroczystość Zesłania Ducha Świętego 2010 r., dz. cyt., s. 47. 
jednoczenia rozproszonej ludzkości ${ }^{73}$, która otwiera się na doświadczenie wspólnoty, które może nią zawładnąć do tego stopnia, że sprawi, iż stanie się nowym organizmem, nowym podmiotem: Kościołem, który ze swej natury jest jeden i wieloraki, przeznaczony do tego, by jako taki żył wśród wszystkich narodów, wszystkich ludów i w najrozmaitszych sytuacjach społecznych ${ }^{74}$.

W rozważaniach dotyczących jedności i wielorakości znajdujemy też wskazanie papieża na czyhającą pokusę żądzy ziemskiej władzy, która fałszuje jedność Ludu Bożego. Ta żądza ziemskiej władzy wyraża się w chęci panowania nad wszystkim, kontrolowania i ujednolicenia wszystkiego ${ }^{75}$, w atmosferze zastraszenia i lęku. Antidotum na jej destrukcyjne działanie jest zaufanie Duchowi Świętemu, bo tylko On może uzdolnić ludzkie serce do miłości i wzajemnego przyjęcia odmienności, które są fundamentem prawdziwej jedności. Żądza ziemskiej władzy dąży do niszczenia indywidualności i zabijania różnorodności (por. 1 P 5, 1-4). Pokorne poddanie się Duchowi Świętemu w uległości owocuje bogactwem różnorodnych darów, różnie realizowanych wskazań duszpasterskich w zależności od posiadanych talentów i możliwości, różnych sposobów i przejawów eklezjalnego życia ${ }^{76}$. Tak przeprowadzona analiza mogłaby być postrzegana jako jednostronna, dlatego Benedykt XVI idzie dalej: Otwartość na Ducha - Pocieszyciela poszczególnych chrześcijan, jak i wspólnot lokalnego Kościoła musi być rozeznawana. Kryterium rozeznania tkwi w odniesieniu do Kościoła powszechnego ${ }^{77}$ i w przezwyciężaniu ciasnej, partykularystycznej mentalności na rzecz otwartości na całą wspólnotę Kościoła ${ }^{78}$. Bo autentyczne życie chrześcijańskie nie oznacza bycia zamkniętym we własnym ,ja", ale otwarcie się na wszystkich; oznacza przyjęcie w sobie całego Kościoła, czy lepiej, pozwolenie w głębi serca, aby on nas przyjął. I konkludując, dodaje następca św. Piotra: „A zatem,

73 Por. LG 13.

74 Benedykt XVI, Homilia w uroczystość Zesłania Ducha Świętego 2010 r., dz. cyt., s. 47.

75 Benedykt XVI, Homilia w uroczystość Zesłania Ducha Świętego 2008 r., dz. cyt., s. 47, zob.

także Kongregacja ds. Duchowieństwa, Dyrektorium o posłudze i życiu kapłanów, 16.

76 Zob. KKK 814.

77 Benedykt XVI, Homilia w uroczystość Zesłania Ducha Świętego 2010 r., dz. cyt., s. 47.

78 Por. Kongregacja ds. Duchowieństwa, dz. cyt., 14. 
kiedy mówię, myślę, postępuję jako chrześcijanin, nie czynię tego, zamykając się we własnym ja, ale czynię to zawsze we wszystkim i wychodząc od wszystkiego" ${ }^{79}$.

\subsection{Modlitwa}

Kolejnym tematem dostrzeżonym w papieskich rozważaniach na uroczystość Pięćdziesiątnicy jest modlitwa. Klasyczna definicja modlitwy określa ją, idąc za Ewagriuszem z Pontu ${ }^{80}$ i Janem Damasceńskim ${ }^{81}$, jako wzniesienie duszy do Boga. Modlitwę można też opisać jak wejście w głąb swego serca ${ }^{82}$, żeby odnaleźć tam miejsce, w którym przebywa Bóg ${ }^{83}$, i gdzie tryska woda Jego stwórczej Miłości. Głębia każdego ludzkiego jestestwa „skrywa” Boga, który pragnie (J 4, 7), by człowiek Go pragnął ${ }^{84}$. W tym świetle modlitwa staje się par excellence spotkaniem pragnienia człowieka z pragnieniem Boga ${ }^{85}$. Urzeczywistnienie tego spotkania wymaga ze strony człowieka odpowiedniej postawy, a jest nią, jak uczy Benedykt XVI, pokorne i w ciszy oczekiwanie na dar Boży ${ }^{86}$, które ma swoją podstawę w objawieniu się Boga. Bóg nie przemawia do człowieka w wichurze, trzęsieniu ziemi ani w ogniu. Jego głos można usłyszeć, jak tego doświadczył prorok Eliasz na górze Horeb, „w szmerze

79 Benedykt XVI, Homilia w uroczystość Zesłania Ducha Świętego 2012 r., dz. cyt., s. 34. To zdanie przypomina tekst św. Jana od Krzyża zamieszczony pod rysunkiem Góra Karmel, czyli Góra Doskonałości: „Gdy zatrzymujesz się nad czymś, przestajesz dążyć do wszystkiego. Aby dojść całkowicie do wszystkiego, musisz zaprzeć się siebie całkowicie we wszystkim”. Św. Jan od Krzyża, Dzieła, przeł. B. Smyrak, Kraków 1986, s. 119.

80 Por. G. Bunge, Ewagriusz z Pontu - mistrz życia duchowego, Kraków 2011, s. 36.

${ }_{81}$ Por. Z. Nabzdyk, Modlitwa - źródło i wyraz duchowości, w: Teologia duchowości katolickiej, red. W. Słomka i in., Lublin 1993, s. 124, por. także KKK 2559.

82 „W konkretnej i generalnie przyjmowanej antropologii biblijnej serce jest siedliskiem świadomej, rozumnej i wolnej osobowości człowieka, miejscem podejmowania decyzji, siedliskiem Prawa nie pisanego (Rz 2, 15) i tajemniczej działalności Boga. Zarówno w Starym, jak i w Nowym Testamencie serce jest miejscem, w którym człowiek spotyka Boga tym spotkaniem, jakie staje się w pełni skuteczne w sercu ludzkim Syna Bożego”. X. Léon-Dufour, Słownik teologii biblijnej, dz. cyt., s. 871.

83 Por. Św. Augustyn, Wyznania, przeł. Z. Kubiak, Warszawa 1987, s. 246.

84 Por. KKK 2560.

85 Por. KKK 2560.

86 Benedykt XVI, Homilia w uroczystość Zesłania Ducha Świętego 2009 r., dz. cyt., s. 8-9. 
łagodnego powiewu" $(1 \mathrm{Krl}$ 19, 12). Prawdziwym objawieniem Boga jest pokorna postać Jezusa, który „nie woła, nie podnosi głosu, nie daje słyszeć swego krzyku na dworze" (Iz 42, 2) ${ }^{87}$. Nie znajdzie więc człowiek Boga w wyniosłości swojej pychy i własnej woli, lecz w „głębokości” (Ps 130,1) pokornego i skruszonego serca ${ }^{88}$. A zatem trzeba człowiekowi schodzić z piedestału swego wywyższenia do pokornego mniemania o sobie ${ }^{89}$, czyli uznania własnej ułomności i zaakceptowania faktu, że jest się duszą poranioną ${ }^{90}$, która nie może ocalić się samodzielnie ${ }^{91}$. Uznanie własnej marności jest bolesne dla natury, bo wiąże się z tajemnicą ogołocenia, która jest misterium crucis $^{92}$ i byłaby niemożliwa do przyjęcia, gdyby nie obecność Ducha Świętego, który „przychodzi z pomocą naszej słabości" $(\mathrm{Rz} 8,26)$. Dlatego wraz z postawą pokornego oczekiwania na dar Boży potrzebne jest, o czym przypomina papież we wszystkich tekstach, nieustanne wołanie o Ducha Świętego - Pocieszyciela. On Duch Prawdy wyprowadza człowieka z zamknięcia się w sobie, burzy w nim wszelkie egoistyczne mury, które dają iluzoryczne poczucie bezpieczeństwa ${ }^{93}$, a w rzeczywistości zamykają na Boga i bliźnich, i udziela nowego życia, które jest poznaniem ,jedynego prawdziwego Boga oraz Tego, którego posłał, Jezusa Chrystusa" (J 17, 3 $)^{94}$. W mocy Parakleta możliwe jest przekraczanie ludzkiej małości, by wejść na wyżyny Chrystusa, które są prawdziwymi wyżynami człowieka ${ }^{95}$ i są życiem Bożym w człowieku; prawdziwym życiem według ducha, które rodzi radość ${ }^{96} \mathrm{i}$ które całej ziemskiej egzystencji nadaje piękno ${ }^{97}$, dostrzegając w każdym jego przejawie nowy akt stworzenia.

87 Por. Benedykt XVI, Homilia w uroczystość Zestania Ducha Świętego 2005 r., dz. cyt., s. 22.

88 KKK 2559.

89 Benedykt XVI, Homilia w uroczystość Zesłania Ducha Świętego 2005 r., dz. cyt., s. 22-23.

90 Uniżanie się, o które tu chodzi, nie jest małodusznym zasklepieniem się w sobie ani tym bardziej samopogardą lub jakimkolwiek rodzajem autodestrukcji, por. Karmelita Bosy, Duch Święty wyprowadza nas na pustynię, przekł. M. J. Janecki, Kraków 2014, s. 77-78.

91 Eremita, Wprowadzenie do modlitwy mistycznej, przekł. Z. Umer, Kraków 2011, s. 6-7.

92 Benedykt XVI, Homilia w uroczystość Zesłania Ducha Świętego 2010 r., dz. cyt., s. 48.

93 Benedykt XVI, Homilia w uroczystość Zesłania Ducha Świętego 2005 r., dz. cyt., s. 22.

94 KKK 684.

95 Benedykt XVI, Homilia w uroczystość Zesłania Ducha Świętego 2005 r., dz. cyt., s. 22.

96 Benedykt XVI, Homilia w uroczystość Zesłania Ducha Świętego 2012 r., dz. cyt., s. 35.

97 Benedykt XVI, Homilia w uroczystość Zesłania Ducha Świętego 2011 r., dz. cyt., s. 28. 


\section{Podsumowanie}

Celem przepowiadania w ramach świętej liturgii, jak uczy Sobór Watykański II, jest głoszenie paschalnego misterium Chrystusa. Szczególnym „miejscem” do opowiadania wielkich dzieł Boga zrealizowanych w śmierci i zmartwychwstaniu Jezusa jest uroczystość Pięćdziesiątnicy; w niej bowiem, przez dar Ducha, tajemnica paschalna znajduje swoje definitywne wypełnienie. Papież Benedykt XVI, głosząc w swoich homiliach orędzie zbawienia doprowadzone do pełni w wydarzeniu Pentekosté, wypełnia ten cel nakreślony przez Sobór Watykański II i w sposób naturalny wiąże je z celebracją liturgiczną. Mocno czerpie też ze źródła biblijnego, co sprawia, że papieskie homilie nabierają solidnych podstaw biblijno-liturgicznych. Z głoszonego kerygmatu wyprowadza ojciec święty pouczenia doktrynalne, szczególnie dotyczące Kościoła, co zostało wykazane w tym artykule. Homilie Benedykta XVI zawierają też wskazania moralne, przekazywane w kluczu pozytywnego orędzia, oraz elementy osobistego świadectwa. Wszystko to ubogaca papieskie przepowiadanie. Homilie Benedykta XVI nie stanowią "gotowców", z którymi można wychodzić na ambonę, gdyż proklamacja słowa Bożego jest tym wymiarem posługi, który cechuje się wyjątkową zmiennością zarówno ze względu na różnice kulturowe dzielące jedno zgromadzenie od drugiego, jak i z racji indywidualnych uzdolnień i ograniczeń poszczególnych kaznodziejów ${ }^{98}$. Może być na pewno pomocą dla wszystkich homilistów w wypełnieniu ich posłannictwa, tak istotnego dla życia Kościoła99.

98 Kongregacja ds. Kultu Bożego i Dyscypliny Sakramentów, Dyrektorium homiletyczne, 3.

99 Kongregacja ds. Kultu Bożego i Dyscypliny Sakramentów, Dyrektorium homiletyczne, 3. 


\section{Summary}

Nauczanie Benedykta XVI o Duchu Świętym na podstawie homilii w uroczystość Zesłania Duch Świętego

W artykule przeprowadzono refleksję teologiczną nad homiliami Benedykta XVI wygłoszonymi w uroczystość Zesłania Ducha Świętego. Głównymi źródłami, z których papież czerpie treść do przepowiadania, są Pismo Święte i liturgia, w mniejszym stopniu korzysta z nauczania ojców Kościoła, magisterium Kościoła i doświadczenia świętych. W omawianych homiliach ojca świętego można wyróżnić pięć zasadniczych tematów teologicznych. Są to: po pierwsze relacja Pięćdziesiątnicy chrześcijańskiej do Pięćdziesiątnicy żydowskiej; po drugie zesłanie Ducha Świętego na tle opowiadania o wieży Babel; po trzecie Duch Święty jako protagonista Kościoła, który jest Ciałem Chrystusa; po czwarte, Kościół jeden i wieloraki, istniejący we wspólnotach lokalnych, a zarazem jako Kościół powszechny; i po piąte, modlitwa, która - jeśli jest praktykowana w postawie pokory i z otwartością na Ducha Świętego - pozwala przekroczyć ludzką małość i wchodzić na wyżyny Chrystusa, będące prawdziwymi wyżynami człowieka.

Słowa kluczowe: Pięćdziesiątnica, Kościół, modlitwa, Benedykt XVI

The Teachings of Benedict XVI about the Holy Spirit in his Homilies on the Solemnity of Pentecost

The article is a theological reflection on the homilies of Benedict XVI preached on the solemnity of Pentecost. The main sources from which the Pope derives the content to preach are the Holy Bible and the liturgy. To a lesser extent he uses the teaching of the Fathers of the Church, the magisterium of the Church and the experience of the saints. In the homilies of the Holy Father, we can distinguish five main theological themes. These are: first, the relation of the Christian Pentecost to the Jewish Pentecost; second, the descent of the Holy Spirit against the story of the Tower of Babel; thirdly, the Holy Spirit, the protagonist of the Church, who is the Body of the Christ; fourth, the one and multiple Church, existing in local communities and also as the universal Church; and fifth, a prayer that, if practiced in an attitude of humility and openness to the Holy Spirit, allows the faithful to surmount human littleness and enter the heights of Christ, which are the true heights of the man.

Keywords: Pentecost, Church, prayer, Benedict XVI 


\section{Bibliografia}

Św. Augustyn, Wyznania, przeł. Z. Kubiak, Warszawa 1987.

Benedykt XVI, Homilia w uroczystość Zesłania Ducha Świętego 2005 r., „L'Osservatore Romano" wydanie polskie 7-8 (275) 2005, s. 21-23.

Benedykt XVI, Homilia w uroczystość Zesłania Ducha Świętego 2006 r., „L'Osservatore Romano" wydanie polskie 8 (285) 2006, s. 12-13.

Benedykt XVI, Homilia w uroczystość Zestania Ducha Świętego 2008 r., „L'Osservatore Romano" wydanie polskie 6 (304) 2008, s. 46-48.

Benedykt XVI, Homilia w uroczystość Zesłania Ducha Świętego 2009 r., „L'Osservatore Romano" wydanie polskie 10 (317) 2009, s. 8-10.

Benedykt XVI, Homilia w uroczystość Zestania Ducha Świętego 2010 r., „L'Osservatore Romano" wydanie polskie 7 (324) 2010, s. 47-48.

Benedykt XVI, Homilia w uroczystość Zestania Ducha Świętego 2011 r., „L'Osservatore Romano" wydanie polskie 8-9 (336) 2011, s. 26-28.

Benedykt XVI, Homilia w uroczystość Zesłania Ducha Świętego 2012 r., „L'Osservatore Romano" wydanie polskie 7-8 (345) 2012, s. 33-35.

Bunge G., Ewagriusz z Pontu - mistrz życia duchowego, przekł. J. Bednarek, A. Jastrzębski, A. Ziernicki, Kraków 2011.

Encyklopedia katolicka, t. 15, red. E. Gigilewicz i in., Lublin 20011.

Eremita, Wprowadzenie do modlitwy mistycznej, przekł. Z. Umer, Kraków 2011.

Gironi P., Dom na skale. Komentarze do czytań niedzielnych i świątecznych. Lata A B C, tłum. K. Stopa, Częstochowa 2003.

Granat W., Dogmatyka katolicka: synteza, Lublin 1967.

Jan Paweł II, Encyklika, Dominum et Vivificantem.

Św. Jan od Krzyża, Dzieła, przeł. B. Smyrak, Kraków 1986.

Karmelita Bosy, Duch Święty wyprowadza nas na pustynię, przekł. M. J. Janecki, Kraków 2014.

Katechizm Kościoła katolickiego. Tekst polski. II wydanie poprawione. Poznań 2012.

Kongregacja ds. Duchowieństwa, Dyrektorium o posłudze i życiu kapłanów „Tota Ecclesia" (31 marca 1994), Watykan 1994.

Kongregacja ds. Kultu Bożego i Dyscypliny Sakramentów, Dyrektorium homiletyczne. Tekst polski. Poznań 2015.

Léon-Dufour L., Stownik teologii biblijnej, tłum. K. Romaniuk, Poznań-Warszawa 1985.

Lurker M., Słownik obrazów i symboli biblijnych, tłum. K. Romaniuk, Poznań 1989.

Matta el-Maskine, Komunia miłości, przeł. J. Dembska, Tyniec-Kraków 2008.

Metzger B., Coogman M., Słownik wiedzy biblijnej, przekł. A. Karpowicz i in., Warszawa 2004.

Misztal H., Doskonali w miłości. Świeccy święci i błogosławieni, Lublin 1992.

Nabzdyk Z., Modlitwa - źródło i wyraz duchowości, w: Teologia duchowości katolickiej, red. W. Słomka i in., Lublin 1993, s. 124-147. 
Ogólne wprowadzenie do Mszału rzymskiego (trzecie wydanie wzorcowe, Rzym 2002). Tekst polski. Poznań 2004.

Paweł VI, Adhortacja apostolska Evangelii nuntiandi.

Paweł VI, Adhortacja apostolska Marialis cultus.

Sławiński H., Chrystus urzeczywistnił Pismo: homilie na rok A, Kraków 2007.

Sobór Watykański II, Konstytucja Lumen gentium

Sobór Watykański II, Konstytucja Sacrosanctum Concilium,

Święta Kongregacja Sakramentów i Kultu Bożego, Wprowadzenie teologiczno-pastoralne do lekcjonarza mszalnego, [w:] To czyńcie na moją pamiątkę. Eucharystia w dokumentach Kościoła, oprac. J. Miazek, Warszawa 1987, s. 33-75. 